\title{
Evaluation of the recommendations part of theses in the field of health management
}

\author{
Kerime GÜLEÇ ${ }^{1}$, Ramazan ERDEM ${ }^{2}$
}

\begin{tabular}{|c|c|}
\hline $\begin{array}{r}\text { Corresponding Author } \\
\text { Kerime GÜLEÇ } \\
\text { DoI } \\
\text { https://10.48121/jihsam.800006 } \\
\text { Received } \\
27.09 .2020 \\
\text { Accepted } \\
\text { 09.04.2021 } \\
\text { Published Online } \\
\text { 30.04.2021 } \\
\\
\text { Key Words } \\
\text { Administration } \\
\text { Healthcare Management } \\
\text { Postgraduate Thesis } \\
\text { Council of Higher Education }\end{array}$ & 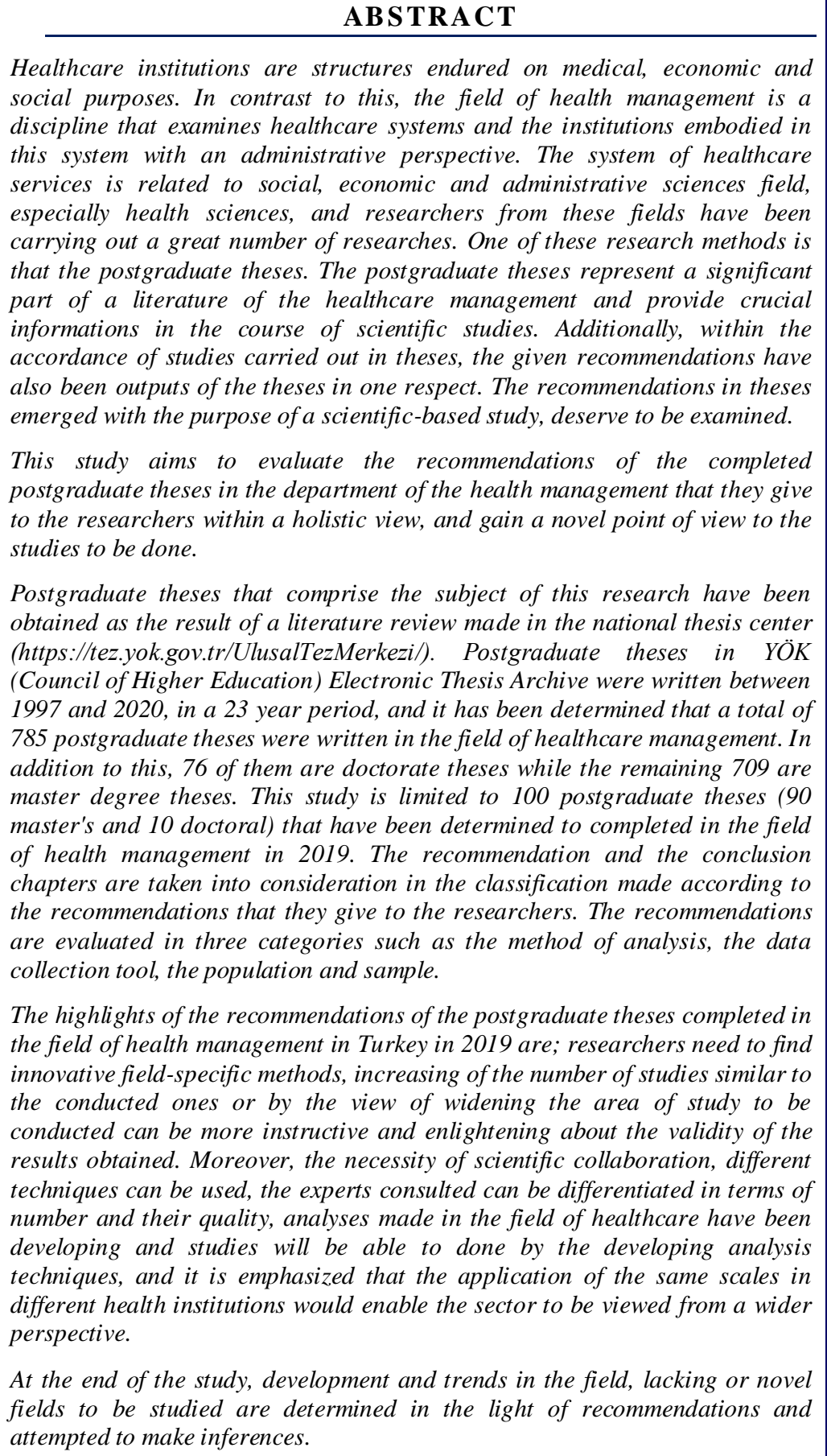 \\
\hline
\end{tabular}

\footnotetext{
${ }^{1}$ İzmir Kavram Vocational School/Medical Documentation and Secreterial Programme/Turkey/kerime.gulec@kavram.edu.tr. https://orcid.org/0000-0001-8352-3592

2 Süleyman Demirel University/Health Care Management/Turkey/raerdem@yahoo.com. https://orcid.org/0000-0001-6951-3814
} 


\section{INTRODUCTION}

The management has been a requirement for humans to achieve their goals through others since people began to create groups with regard to reach their goals that they could not achieve individually.

Management is all the decision-making and carrying out stages of using efficiently and effectively the pecuniary resources, raw materials, fixtures and time managing, especially with its main resource being human with regard to achieve the stated goals (Eren, 2011: 14).

Although there are many definitions used in the literature, the definition that management scientists most agree on the word "management" is "working through others". (Koçel, 2010: 59)

As a result of globalization, the issues dealt with in the every aspect of human lives such as technological developments, the aim of getting a maximum output with a minimum input, increasing of needs, scarcity of resources have shown their presences also in the healthcare sector. On the ground that the misuse of resources in healthcare organizations make human life end up, the necessity of having experts and professionals in administration is being arisen.

Healthcare organizations by its nature a system that are challenging to manage, complex, open to development and change. These healthcare organizations and their managers at various levels have become extremely a significant working area in both our country and internationally (Çimen, 2010: 138).

The main field of health management is related to the administrative side of organizations which provide healthcare services. The healthcare management does not display a management figure that both act with the aim of using economically the scarce resources required for diagnosis and treatment, and making the healthcare professionals' work difficult. On the contrary, healthcare management performs collaboratively with the healthcare professionals with regard to facilitate their work within the scope of increasing the health and the satisfaction of patients (Yıldırım Kaptanoğlu, 2011: 20).

According to the report of SAYÇEP in 2017, it is defined that "Health institutions management is a process involving interrelated social and technical functions and activities that occur within a specific formal organization with regard to achieve predetermined goals through human and other resources." (Health Management National Core Education Program Report in 2017)

The US Healthcare Management Education Commission describes the concept of healthcare management "It is the planning, organizing, mobilizing, coordinating and controlling of resources and processes that enable medical care and healthy environmental demands to be met by providing definite services to individuals, organizations and societies" (Tengilimoğlu, 2012:539).

The first health management training and development in our country is as follows: "Health Administration High School was established within the Ministry of Health in 1963, as parallel to the development and process of change at health management in the world. Then, by virtue of the Senate of Hacettepe University Law no. 5 June 1970/80, High School Of Hospital Management was established and gave postgraduate training until 1975. By the date 6.11.1975 and by virtue of Law no. 75-81, graduate training programme was opened and the name of the school was changed into "High School Of Healthcare Management". The high school both affiliated to the ministry of Health and to Hacettepe University was joined as a single school within Hacettepe University by virtue of the Law no. 20 July 1982/4. In addition, by virtue of the Higher Education Council recommendation Law no. 24 April 2006/008913 and decision of the Senate Of Hacettepe University, it was affiliated to the Faculty of Economics and Administrative Sciences as "Department Of Healthcare Administration". In a meeting of Higher Education Executive Committee held on 16.11.2016, it was decided to change the name Department of Healthcare Administration within the Faculty of Economics and Administrative Sciences into "Healthcare Management" pursuant to Articles 7/d-2 and 7/h amended by Law no. 2880, within the virtue of Law no.2547 (http://www.sid.hacettepe.edu.tr/tr/menu/tarihce-53).

Many universities in Turkey comprised health management undergraduate and graduate training programmes into their education systems. The numerical distribution of undergraduate training programme of the healthcare management at universities in Turkey is as follows: while 47 of them are state universities, the remaining 20 are foundation universities, with a total number of 67 universities have been providing an undergraduate training in healthcare management (https://yokatlas.yok.gov.tr/lisansbolum.php? $\mathrm{b}=10238$ ).

It is known that the education in the field of healthcare management in Turkey has been gradually gaining importance and has been increasing mainly as a high school education. Dating from 2017-2018 Fall Semester, assume that the distribution of master programmes with thesis and non-thesis master programmes of healthcare management according to the universities are examined. There are a total of 52 health management graduate programmes in state universities while 23 of them with thesis and the remaining 29 of them non-thesis. In addition, while 
$44 \%$ of master programmes in state universities are with thesis, the remaining $56 \%$ of them are non-thesis. Moreover, in foundation universities, there are a total of 48 health management graduate programmes while 25 of them with thesis and the remaining 23 of them with non-thesis. Besides while $52 \%$ of master programmes are with thesis in the foundation universities, the remaining $48 \%$ of them are non-thesis (Güngör Önlen ve Öngel, 2018:889).

In recent years, the healthcare management graduate programmes have been increasing in both state and foundation universities. In order to discuss topically the doctorate programmes among the healthcare management graduate programmes, the key word "health management doctorate programme" is written to Google search engine and the following results are found: there are six foundation universities that have health management doctorate programme such as Üsküdar University, Medipol University, Okan University, Acıbadem University, Biruni University, Lefke Avrupa University, and there are seventeen state universitie that have health management doctorate programme such as Sakarya University, Muğla University, Hacettepe University, Marmara University, Ondokuz Mayıs University, Trakya University, Mersin University, Kayseri University, Frrat University, Ankara University, Sağlık Bilimleri University, İstanbul University, Cerrahpaşa University, Selçuk University, Ankara Hacı Bayram Veli University, Düzce University, Süleyman Demirel University, Ankara Yıldırım Beyazit University.

\section{METHOD}

\section{Model of the Research}

This study exhibits the thematic distribution of postgraduate education theses in the field of healthcare management in Turkey. Therefore, in this study the descriptive survey model is adopted.

\section{Population and Sample}

Postgraduate theses that comprise the subject of this research have been obtained as the result of a literature review made in the national thesis center (https://tez.yok.gov.tr/UlusalTezMerkezi/).

Table 1. The Distribution of Theses According to the Universities and Degrees

\begin{tabular}{|c|c|c|c|c|}
\hline University & $\begin{array}{l}\text { Postgraduate } \\
\text { Degree }\end{array}$ & $\begin{array}{l}\text { Doctorate } \\
\text { Degree }\end{array}$ & $\begin{array}{c}\text { Total } \\
\text { Number }\end{array}$ & Percentage \\
\hline Acıbadem Mehmet Ali Aydınlar University & 3 & & 3 & \\
\hline Ankara University & 1 & & 1 & \\
\hline Bahçeşehir University & 1 & & 1 & \\
\hline Çanakkale Onsekiz Mart University & 1 & & 1 & \\
\hline Düzce University & 3 & & 3 & \\
\hline Firat University & 1 & & 1 & \\
\hline Gazi University & 3 & 1 & 4 & \\
\hline Hacettepe University & 1 & 3 & 4 & \\
\hline İstanbul Aydın University & 1 & & 1 & \\
\hline İstanbul Gelișim University & 1 & & 1 & \\
\hline İstanbul Medipol University & 6 & & 6 & \\
\hline İstanbul University & 4 & 4 & 8 & \\
\hline İstanbul Yeniyüzyıl University & 1 & & 1 & \\
\hline Kahramanmaraş Sütçü İmam University & 5 & & 5 & \\
\hline Marmara University & 2 & 1 & 3 & \\
\hline Muğla S1tk1 Koçman University & 1 & & 1 & \\
\hline Necmettin Erbakan University & 5 & & 5 & \\
\hline Nişantaşı University & 2 & & 2 & \\
\hline Okan University & 1 & & 1 & \\
\hline Ondokuz Mayıs University & 4 & & 4 & \\
\hline Sakarya University & 13 & & 13 & \\
\hline Selçuk University & 1 & & 1 & \\
\hline Sivas Cumhuriyet University & 8 & & 8 & \\
\hline Süleyman Demirel University & 5 & & 5 & \\
\hline Tekirdağ Namık Kemal University & 5 & & 5 & \\
\hline Trakya University & 6 & & 6 & \\
\hline Üsküdar University & 5 & 1 & 6 & \\
\hline Total & 90 & $\mathbf{1 0}$ & 100 & \\
\hline
\end{tabular}


Postgraduate theses in YÖK Electronic Thesis Archive, it has been determined that between 1997 and 2020, in a 23 year period, a total of 785 postgraduate theses were written in the field of healthcare management. In addition to this, 76 of them are doctorate theses while the remaining 709 are master degree theses. This study is limited with 100 postgraduate theses (90 of them master degree and the remaining 10 doctorate degree) which were determined to be completed in the field of healthcare management in 2019, as also seen in table 1, and in this study random sample method is adopted. According to the research data, it is seen that most theses are written at postgraduate degree. Furthermore, there is a considerable difference between postgraduate theses and doctorate theses. This difference is thought to be due to the fact that the graduate program in the relevant universities started earlier and also that there has no doctorate program in most universities.

The distribution of theses according to the institutes is given in the Table 2 below. When the given table is examined, it is seen that the theses within the department of health management field are written under four institutes. It is seen that under these institutes most theses are written within the graduate school of health sciences. This situation is thought to be due to the fact that health-related issues in the field of health management have been studied predominantly.

Table 2. The Distribution of Theses according to the Institutions

\begin{tabular}{|l|c|}
\hline Instutions & Number \\
\hline Institution of Business & 12 \\
\hline Institution of Graduate School & 8 \\
\hline Institution of Health Sciences & 49 \\
\hline Institution of Social Sciences & 31 \\
\hline Total & $\mathbf{1 0 0}$ \\
\hline
\end{tabular}

In the light of the research area, theses are examined by considering five fields. These fields are shown in the Table 3 given below. In the analysis, it is seen that healthcare facilities are mostly preferred as the research field in the theses, and followed respectively by more than one field, provinces, students, healthcare sector stakeholders, OECD countries. The fact that mostly health institutions are preferred as research fields in the study indicates that the researchers study on healthcare professionals operating in the health sector.
Table 3. The Distribution of Theses According to the Research Field

\begin{tabular}{|l|c|}
\hline Research Fields & Number \\
\hline $\begin{array}{l}\text { Healthcare Facilities (Hospitals, } \\
\text { Geriatric Care Centres, Family } \\
\text { Physicians etc.) }\end{array}$ & 80 \\
\hline $\begin{array}{l}\text { Healthcare Sector Stakeholders } \\
\text { (Tourism, Pharmacy, Airport,...) }\end{array}$ & 4 \\
\hline Province-based (Patient Profile) & 7 \\
\hline OECD Countries & 3 \\
\hline Students & 6 \\
\hline Total & 100 \\
\hline
\end{tabular}

The qualitative, quantitative and mixed research approaches are considered in the theses while analyses are carried out. As it can be seen in Table 4, the quantitative research approach is mostly preferred as the research approach. This research approach is followed respectively by qualitative research approach and mixed research approach. It is notable that quantitative studies are the majority of the study.

Table 4. The Distribution of Theses According to the Research Approach

\begin{tabular}{|l|l|}
\hline Approach & Number \\
\hline Quantitative & 88 \\
\hline Qualitative & 10 \\
\hline Mixed & 2 \\
\hline Total & 100 \\
\hline
\end{tabular}

\section{Collection of Data and Analysis}

The epistemological document analysis method is adopted in this research (Karadağ, 2009). In the first stage of document analysis, the postgraduate theses and doctorate theses in the sample group are computerized in a pdf format from the website of YÖK (Council of Higher Education) Documentation Department. In the second stage, in the light of recommendations that they give to the researchers, the computerized theses are analyzed according to the year, the owner of the thesis, university, graduate status, research recommendation methods. 


\section{RESULTS AND DISCUSSION}

In this study, it is aimed to evaluate the recommendations of the completed postgraduate thesis in the department of the health management that they give to the researchers within a holistic view, and gain a novel point of view to the studies to be done.

The $50 \%$ of postgraduate theses included in the sample group are evaluated in the category of recommendations that they give to the researchers. While 44 of the theses examined in this category are master degree theses, the 6 of them are doctorate degree theses.

When recommendations given to the researchers are considered within the context of the population and sample;

Within the scope of study limitations, issues such as time interval, how honestly and sincerely participants answered the survey articles are discussed. In order to eliminate these limitations and generalize the results, this research can be broaden by applying this survey to large masses in different geographical regions, in different sectors such as state institutions and organizations, healthcare executives, different kind of patient groups, oral and dental health clinics, primary healthcare services and secondary healthcare services, tertiary healthcare services, insurance agencies.

In regard of analyzing method of recommendations given to the researchers;

Approaching as a state hospital affiliated to the Ministry of Health and private hospital with two different distinctions, different sectors and in different regions. Furthermore, students studied in separate university and departments, dividing healthcare professionals into their professions and separately applying surveys are proposed to make comparison in view of causality studies.

Research Methods for the Recommendations given to the researchers ;

Innovative field-specific methods targeting both healthcare professionals and the public, utilizing novel medical technologies, interviews with senior hospital managers or focus group discussions, designing studies in a mixed structure that has not only a quantitative but also a qualitative pattern can be proposed. With the purpose of increasing evidencebased knowledge in quality improvement studies in care services and for "specialization of care" the number of qualitative researches should be enhanced with the aim of learning the perception of qualified care the groups of disease/disability. In recent years, the increasing number of academic studies has been providing basis for meta-analysis method, and metaanalyzing method has been proposed.

Data Collection Tool for the Recommendations given to the researchers ;

Having developed by applying current data in terms of relative efficiency measurement in the field of health. The AAS method integrated into SWOT analysis and other multi-criteria decision making techniques can be adopted. When the theses written in the field of healthcare management are examined with regard to recommendations that they give to researchers; the recommendations such as the increasing number of identical studies or expanding the area of study, with the different research methods, the development of the scales used or the data obtained can be more instructive and enlightening about the validity of the results obtained by differentiating the sample and the universe are presented in the results of theses.

\section{CONCLUSION AND RECOMMENDATIONS}

The highlights of the recommendations of the postgraduate theses completed in the field of health management in Turkey in 2019 are; researchers need to find innovative field-specific methods, increasing of the number of studies similar to the conducted ones or by the view of widening the area of study to be conducted can be more instructive and enlightening about the validity of the results obtained. Moreover, the necessity of scientific collaboration, different techniques can be used in the studies, the experts consulted can be differentiated with regard to number and their quality, analyses made in the field of healthcare have been developing and new studies will be able to done by the developing analysis techniques. Furthermore, the adoption of the identical scales in different health institutions will enable the sector to be viewed from a wider perspective.
At the end of the study, development and trends in the field, lacking or novel fields to be studied are determined in the light of recommendations and attempted to make inferences:

Nowadays, the issue of health management has become enormously a significant field of study in our country. There is a requirement for novel studies adopting different research methods and data collection tools.

Managers are of great importance in creating a hospital culture that can provide high performance. Executives should be able to analyze the service processes in the hospital well and increase the value of healthcare services.

Healthcare field is one of the complex and difficult system for the reason of its rapid technological 
developments and labour-intensive nature. Studies have shown that these difficulties will be overcome by the knowledge, skills and abilities of executers, employees, stakeholders, policy makers and researchers.

There has been a significant increase in the number of theses made in the field of Health Management in recent years. Issues related to many subheadings of this field has still being required a lot of research.

In the interest of shaping the future in this field, studies should be produced by taking the recommendations of prior studies into consideration. It is also crucial for researchers to consider recommendations in postgraduate studies in view of building healthcare management discipline on solid basis.

Acknowledgments: None

Conflict of Interest: The authors declare that they have no conflict of interest.

Ethical Approval (Must be answered): None

Funding: None

\section{REFERENCES}

Çimen, M. (2010), "Sağlık Yönetimi ve Sağlık Yönetim Eğitimi”, Acıbadem Üniversitesi Sağlık Bilimleri Dergisi, Cilt.3, Sayı.1, 136139.

Eren, E. (2011). Yönetim ve Organizasyon (Çağdaş ve Küresel Yaklaşımlar) (10.Baskı), Beta Basım, İstanbul.

Güngör Önlen, B., \& Öngel, V. (2018). Türkiye'de Sağlık Yöneticiliği Eğitimi Ve Yüksek Lisans Öğrencilerinin Öz Değerlendirmeleri. Süleyman Demirel University Journal of Faculty of Economics \& Administrative Sciences, 23.

Koçel, T. (2010). İşletme Yöneticiliği. Genişletilmiş 12. Bask1, İstanbul: Beta Basım Yayım Dağıtım A.Ş.

Sağlık Yönetimi Ulusal Çekirdek Eğitim Programı, 2017 Raporu/ http://tyyc.yeniyuzyil.edu.tr/Page/SBF/Saglik_Yonetimi/files/Sayce p-2017.pdf
Tengilimoğlu, D. (2012). Hasta Yönetimi ve Organizasyonu. Tatar M. (Ed.), Sağlık Kurumları Yönetimi I, Birinci Baskı, Eskişehir: T.C. Anadolu Üniversitesi Yayını.

Yıldırım Kaptanoğlu, A. (2011). “Sağlık Yönetimi”, Yıldırım Kaptanoğlu A. (Eds.), Sağlık Yönetimi, Birinci Baskı, Beşir Kitabevi, İstanbul

http://www.sid.hacettepe.edu.tr/tr/menu/tarihce-53, (Erișim Tarihi:10.02.2020)

https://yokatlas.yok.gov.tr/lisans-bolum.php?b=10238, (Erişim Tarihi: 10.02.2020)

https://tez.yok.gov.tr/UlusalTezMerkezi/, (Erișim Tarihi:14.01.2020) 